The Social Sciences 14 (12): 413-422, 2019

ISSN: $1818-5800$

(C) Medwell Journals, 2019

\title{
The Factors of Permanence of Civilization Through the Hadith of the Prophet (Peace and Blessings of Allah Be upon Him) Narrated by Almostawred Alfahri
}

\author{
Mahmoud Lafee Obeedan Khalaf and Osama Soud Muhy Aldeen Kreishan \\ Department of Islamic Studies, College of Literature, Al-Husain Bin Talal University, \\ Ma'an, Jordan
}

\begin{abstract}
The present study aims to identify the reasons leading to the survival of civilizations based on the Hadith of the Prophet (Peace and Blessings of Allah Be upon Him). It aims to identify those reasons from the perspective of Almostawred Alfahri. Those reasons are derived from the teachings of Islam. Such teachings aim at regulating various aspects of life. Based on Hadith, the civilizations that survive have several attributes. Such attributes are not related to being religious or not. These attributes are general attributes. Allah asked people to seek possessing those attributes. When possessing such attributes, people shall become good Muslim worshippers.
\end{abstract}

Key words: Civilization, permanence of civilization, hadith alsahabi almustawred, Islam, human, qualities

\section{INTRODUCTION}

\section{The first topic}

Overthrow: The script of the Hadith of the Prophet (peace and blessings of Allah be upon him) narrated by Almustawrid May Allah be pleased with him Mustawrid al-Qurashi said to Amr Bin Alas: I heard from Allah's Messenger peace and blessings of Allah be upon him: the last hour would come (when) the Romans would form a majority amongst people. 'Amr said to him (Mustaurid Qurashi): See what you are saying? He said: I say what I heard from Allah's Messenger peace and blessings of Allah be upon him (Thereupon he said: If you say that, it is a fact for they have four qualities. They have the patience to undergo a trial and immediately restore themselves to sanity after trouble and attack again after fight. They (have the quality) of being good to the destitute the orphans and to the weak and fifthly, the good quality in them is that they put resistance against the oppression of kings (Abu Al-Fida, 1998).

In the Hadith, we find the reasons of the rum being the majority of people and Outperforms people by their abundance and permanence of their civilization.

Abundance could have the meaning of abundance in number due to their stability in life and what depends on it or abundance in strength as they are the most powerful and most influencing and history and realty are witnesses and they are the owners of the civilization that preceded Islam and is still going on and will remain until the end of time.
Who are the Romans mentioned in the Hadith? Romans are an ancient people who are mentioned in Quran in verse (30:2). A chapter of the Quran is also named after the Romans. Almighty said: (Alif, Lam, Meem (Abu Al-Fida, 1998). The Roman Empire has been defeated2 In a land close by but they, (even) after (this) defeat of theirs will soon be victorious3) Romans are the dynasty of Al-Issa bin Isaac bin Ibrahim and they are the cousins of people of Israel they are also called Bano Alasfar (3).

Rome was founded in Italy and the Roman state was established which spread over most of Europe and most of the civilized countries in Asia and Africa as Cartagena, Egypt, Greece, Asia Minor, Palestine, Syria and other Asian countries were in the possession of the Romans (Abu Al-Qasim, 1991).

The Roman kingdom was the greatest in the world but like all other kingdoms it splits into small separated parts (Abu Abdullah, 2000) and they are now the known western civilization living in Europe and the place that Europeans emigrated to like the American united states and Canada and Australia.

In this summary, we aim to point to five qualities which were mentioned in the Hadith that makes the roman keep the permanence of their civilization, there qualities are authentic and basic in our religion and we will define the Islamic root of them. 
The Soc. Sci., 14 (12): 413-422, 2019

\section{DEFINITION OF CIVILIZATION IN LANGUAGE}

Civilization is the opposite of barbarism and Bedouin. And civilized living in civilizations. Said: what kind of badya men (Bedouin), we are if we considercivilization. "alasma'ei".

Definition of civilization in the term: it's the human trying to explore, invent, think, organize and Benefiting the nature to reach a better life which is the combine of all peoples efforts (Abu Al-Qasim, 1986).

Another definition: It is a social system that combine the spiritual elements like thoughts, traditions, values, customs, feelings, tastes and concepts and the material elements like professions, livings, earnings, industries, food, close, methods and styles. Abu Khalil (1996) as it is the improvement of a humans social mental and intellectual life and having all types of comfort an benefiting the nature in the best way. After this overthrow, we will talk about the five qualities each in deferent sectors.

\section{The second topic}

Patience to undergo a trial: Patience to undergo a trial is the first quality mentioned in the Hadith when said "They have the patience to undergo a trial", this is the most important quality for people being stable and settle in life since all societies go through tribulation that will eventually end without leaving disastrous results because panicking when suffering would multiplies the negative effects or may even cause destruction that will constitutes an obstacle for next generation to develop the civilization. Patience or tolerance is (taking time before punishing from only those who are capable of punishment and who disciplines but for those who's not it's not patience it's ذل ولكن صفح احلام : ذل لاصفـح

Tolerance is the opposite of foolishness and that's good because foolishness is swift and hasty and tolerance is grace and delay (Abu Al-Fidaa, 1982). Then, patience is restrain self and temper when raging anger. Therefor, patience and delaying and grace when tribulation or blur vision is praised because it makes the persons see things clearly and truly as it is and be able to make right decision that fits the difficulties which the society go through. Al-Haleem (Arabic: الحليم) is one of the names of Allah mentioned in 11 verses in Quran.

2:225 Allah does not impose blame upon you for what is unintentional in your oaths but He imposes blame upon you for what your hearts have earned. And Allah is forgiving and forbearing.

2:263 kind speech and forgiveness are better than charity followed by injury. And Allah is free of need and forbearing. Meaning of Allah name Al Haleem is that he is the forbearing and does not hasten the punishment for his slave who disobey him, only he has totally forbearing for all slaves even those who's non believer in him and those who disobey him and make many mistakes. So, he forgives and does not give the sinners the punishment they deserve instantly but he encourages them to repent and gives them time to turn to Him even though he doesn't forget if they incise and keep on oppression and didn't repent. Al Haleem is one who keeps bestowing blessings, both visible and hidden on his creation, even the disobeying and the sinner.

Allah doesn't correspond to the sinner with their sins, he admonish them to repentand does not hasten the punishment, so, they return to him. Allah almighty is Haleem Afuw (forbearing and pardoner) he is totally forbearing and completely pardoning and thins two great names are regarding to the sinners with their sins and injustice of criminals, as the sins require urgent punishment but Allah Haleem doesn't hasten, so, they repent and his pardon requires forgiveness of sins if the slaves ask forgiveness and repent and believe in Allah and did good deeds. His patients expand the heavens and the Earth (Abu Bakr, 1872).

Allah Almighty described the best of human beings and they are prophets and apostles as such because of its high status in those who want to reform and change the societies, as the best reformers are the prophets and apostles Allah Almighty described his Khalil Ibrahim peace be upon him. he said in 9:114 Indeed was Abraham compassionate and patient. 11:75 Indeed, Abraham was forbearing, grieving and [frequently] returning [to Allah] Then when he was told that he will have Ismail peace be upon them Allah said in 37:101. So, we gave him good tidings of a forbearing boy.

Ibn Taimeia talked about this verse he said it held three good tidings which are the child is a male and he reaches adultness and he'll be compassionate. What patient is greater than his patient when his father told him that he was ordered to sacrifices him then he said in 37:102. "He said, "O my father, do as you are commanded. You will find me, if Allah wills, of the steadfast”,

There for this discretion was for prophets and especially for Ibrahim (Abu Al-Hasan, 2006). We can define Al Haleem meaning in the following poetry for Alarji (Taqi Al-Din Abu Al-Abbas, 1995).

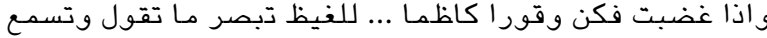

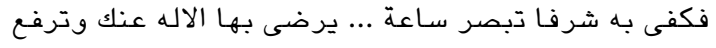

And Arwa Ibn Zubair said about clemency (Abu Zakaria, 1972):

$$
\text { لن يبلغ المجد اقوام وان شرفوا ... حتى يذلوا وان عزوا لاقوام }
$$


و ايشتموا فترى الالوان مشرقة ... لاعفو ذل ولكن عفو اكرام

And Allah said in many other verses like in 7:199 Take what is (Abu Al-Qasim, 1991) given freely, enjoin what is good and turn away from the ignorant.

Alzamakhshary said about this verse that it combined all of the high morals which Allah asked his prophet to present.

Allah also said in 41:34 and not equal are the good deed and the bad. Repel [evil] by that [deed] which is better; and thereupon the one whom between you and him is enmity [will become] as though he was a devoted friend.

It was narrated from Ibn Abbas that Allah ordered the believers to be patient when they were angry and pardon and to forgive when they were offended, if they do so, Allah will exalt them from Satan and he'll become as a devoted friend.

Altabari said about this verse O Mohammed If you remain quiet in response to an abuse, it will be mere goodness but it will not silence the abuser. But if you express good wishes for him in response to his abuses, even the most shameless opponent will feel ashamed, and then would hardly ever be able to employ invectives against you and he'll become as a close relative or a friend (Ahmed and Abdul-Hamid, 2008).

The messenger peace be upon him was patient in his actions and sayings and 'Abdullah bin Mas'ud (May Allah be pleased with him) reported: I can still recall as if I am seeing the Messenger of Allah (peace be upon him) resembling one of the Prophets whose people scourged him and shed his blood while he wiped blood from his face, he said: "O Allah! forgive my people because they certainly do not know" (Ahmad, 1978). And another situation reported by Aysha may Allah be pleased with her that she asked the Prophet (peace be upon him), 'Have you encountered a day harder than the day of the battle) of Uhud?” The Prophet (peace be upon him) replied, "Your tribes have troubled me a lot and the worse trouble was the trouble on the day of 'Aqaba when I presented myself to Ibn `Abd-Yalail bin `Abd-Kulal and he did not respond to my demand. So, I departed, overwhelmed with excessive sorrow and proceeded on and could not relax till I found myself at Qarnath-Tha-alib where I lifted my head towards the sky to see a cloud shading me unexpectedly. I looked up and saw Gabriel in it. He called me saying, 'Allah has heard your people's saying to you and what they have replied back to you, Allah has sent the Angel of the Mountains to you, so that, you may order him to do whatever you wish to these people'. The angel of the mountains called and greeted me and then said, " $\mathrm{O}$ Muhammad! order what you wish. If you like, I will let Al-Akh-Shabain (i.e., two mountains) fall on them". The Prophet (peace be upon him) said, "No but I hope that Allah will let them beget children who will worship Allah alone and will worship none besides Him”. The actions that shows clemency and patient in the prophet biography are plenty, we can see when he forgive the people in Mecca when he conquest Mecca, that's the way his patient was.

In his saying (peace be upon him) to Ashaj Abdulqais (You possess two qualities that Allah loves. These are clemency and tolerance) (Abdulaziz and Al-Qawzi, 1999).

Another Hadith saying "Deliberateness is from Allah and haste is from the Ash-shaitan". As explained, foolishness is hasten and recklessness.

Abu Hurairah (May Allah be pleased with him) reported: messenger of Allah (peace be upon him) said, "The strong man is not one who is good at wrestling but the strong man is one who controls himself in a fit of rage". The one who have clemency is the one who controls himself when anger, Alkhatabi said (don't be angry and avoid the reasons that makes you angry or bring anger to you, also said don't be angry it will cause vanity because you'll be angry for something you want and will bring you to vanity, the messenger said that the strongest people is the one who controls themselves at a fit of rage (Abu Abdullah, 2000).

Now the important question is how being patient to undergo a trial is a reason to make solid society? We need to clarify the definition of trial and how is it treated with patient?

The Trial is: Allah said in 51/13 [It is] the day they will be tormented over the fire, the companions of the prophet were tormented to leave their religion. Allah said in 2:191 and fitnah is worse than killing.

Trial is torturing and it is calamity and it is wars between people ${ }^{(25)}$ so, it's calamity that drops on people. ${ }^{(26)}$ Another definition is the intensity of adversity (Mohammed, 1999).

Examples for calamities: Wars, epidemics, drought, rain, floods, earthquakes and tornadoes. For Muslims the imam Alnawawi said that pray in Qunout (with honest heart) if you had a calamity (Mohammed Bin Isa, 1998).

To understand how patient at a trial is one reason for society to continue, we need to notify to three pauses:

First pause: When calamities come down on people, things become confusing and judgment becomes difficult and it tolerates more than one position and each position has implications then patient is required and acting carefully not hasty and we find many similar situations in the prophet biography. Like the position of the companions when there was a rumor of the death of the Prophet peace be upon him in the conquest of Uhd and that was the biggest calamity for Muslims, some Muslims have had a negative attitude and some have had a positive attitude and in the narrated story Anas bin Alnadur passed a group of Muslims who had surrender after hearing the 
rumor and he told them: what are you waiting? And they said that the prophet had died. And he said: then stand up and die for what he died for. Then he met Sa'd Bin Moa'd and he told him that he can smell the Jannah wind before Uhd and he fought until he was martyred and he had seventy hits.

This situation reveals the people are different in handling calamities, so when a calamity falls down there must be patient and taking manners carefully and look to consequences because the decision at that point is very important and dangerous because it could destroy nations and civilizations or it could save the permanence of the civilization and in the previous story if the death of the prophet was true it holds two meaning one people should surrender and destroys everything that was built or continuing the prophet march and walk in the right way and that is the best way to deal with the situation.

The difference between both cases is very clear the muslims who surrender made a disastrous decision but Anas made a valuable and patient decision and he presented the bright side in the calamity when he said stand up and die for what he died for as continue what the prophet build, continue his da'wa his religion his bath.

Second pause: Sometimes emotions like anger, joy or sadness overcome on the mind of the human behave and act in a way he would regret when he the vision is clarified and knowledge is right. For example the anger of Omar Bin Alkhatab may allah be pleased with him and some of the companions in Al Hudaybiyah Magistrate and the story says (Sahal b. Hunaif stood up on the day of Siffin and said: O ye people, blame yourselves (for want of discretion); we were with the Messenger of Allah (SAW) on the Day of Hudaibiya. If we had thought it fit to fight, we could fight. This was in the truce between the Messenger of Allah (SAW) and the polytheists. Umar b. Khattab came, approached the Messenger of Allah (SAW) and said: Messenger of Allah, aren't we fighting for truth and they for falsehood? He replied: By all means. He asked: Are not those killed from our side in Paradise and those killed. from their side in the Fire? He replied: Yes. He said: Then why should we put a blot upon our religion and return while Allah has not decided the issue between them and ourselves? He said: Son of Khattab, I am the Messenger of Allah. Allah will never ruin me (The narrator said): Umar went away, but he could not contain himself with rage. So, he approached Abu Bakr and said: 'Abu Bakr, aren't we fighting for truth and they for falsehood? He replied: Yes. He asked: Aren't those killed from our side in Paradise and those killed from their side in the Fire? He replied: Why not? He (then) said: Why should we then disgrace our religion and return while God has not yet decided the issue between them and ourselves? Abu Bakr said: Son of Khattab, verily, he is the Messenger of Allah and Allah will never ruin him. (The narrator continued): At this (a Sura of) the Qur' an (giving glad tidings of the victory) was revealed to the Messenger of Allah (SAW). He sent for Umar and made him read it. He asked: Is (this truce) a victory? He (the Messenger of Allah) replied: Yes, at this Umar was pleased and returned).

Another situation it was during this time while the treaty was being written that abu jandal, suhail's son, appeared on the scene. He was brutally chained and was staggering with privation and fatigue. The prophet [PBUH] and his companions were moved to pity and tried to secure his release but suhail was adamant and said: "to signify that you are faithful to your contract, an opportunity has just arrived". The prophet [PBUH] said: "but the treaty was not signed when your son entered the camp". Upon this, he burst forth and said "but the terms of the treaty were agreed upon". It was indeed an anxious moment on the one hand, abu jandal was lamenting at the top of his voice, "am i to be returned to the polytheists that they might entice me from my religion, o muslims!” but on the other hand, the faithful engagement was also considered to be necessary, above all other considerations. the prophet's heart welled up with sympathy but he wanted to honour his word at all costs. He consoled abu jandal and said, "be patient, resign yourself to the will of Allah. Allah is going to provide for you and your helpless companions relief and means of escape. We have concluded a treaty of peace with them and we have taken the pledge in the name of Allah. We are therefore, under no circumstances prepared to break it”. 'Omar bin al-Khattab could not help giving vent to the deep-seated agony of his heart. He rose to his feet uttering words implying deep hatred and extreme indignation and requested Abu Jandal to take his sword and kill Suhail but the son spared his father. However, in silent resignation was therefore, Abu Jandal borne away with his chains.

This situation had a huge trial, since, the Muslims were longing for Tawaf in the Kaaba but they returned back to Madina without doing Tawaf though the news came in a vision to the Messenger in Quran 48:27. Certainly has Allah showed to His Messenger the vision in truth. You will surely enter al-Masjid al-Haram, if Allah wills in safety with your heads shaved and [hair] shortened, not fearing [anyone]. He knew what you did not know and has arranged before that a conquest near [at hand]. And the hardest thing on Muslims was that a man of them returned against his well to polytheists and yet the messenger kept his part of the treaty knowing that it's the right thing to do. This situation taught the companions the meaning of patience to undergo a trial and not to let feelings overcome mind. For that Omar Bin Alkhattab said (I still do charity, fast, pray and release slaves for what I'v made that day and fear of the words that I spoke. He also said I released many and fasted a lot). 
Third pause: In some great situations it requires the decision maker to be firm without leaving clemency. It is the patient that makes the person have a visionary insite and predict best results. Unlike those who panic his decision becomes hesitant and his insight is confused, after the death of the Prophet peace be upon him there was an army ready to go to Syria and in that time it was a the biggest calamity that happened to Muslims that needed a special type of clemency and patience which characterized in the first generation of companions, may Allah be pleased with them and the attitude of Abu Baker Alsadeeq showed he most wonderful example, since, he was first disciple of the Messenger of Allah peace be upon him and it is in the story telling: Abu Hurayrah said:if it wasn't for Abu Bakr, no one will worship Allah then said the second, then said the third, he was told (Abu Hurayrah): meh, Abu Hurayrah.He said: The Messenger of Allah peace be upon him arranged an army of seven hundred headed by Osam bin zaid to Syria and when it came down Zhi khashab Allah took the prophet Mohammed soul and the Arab around the Madina renounces the religion and the companions of the Messenger of Allah gathered and went to him and told him: first renounce the Arab, you are sending an army to fight the rum and the Arab around Madina renounced their religion? And he said: o Allah there is no other God but Allah if I saw shackles in the legs of the wives of the Messenger of Allah, peace be upon him, I will not hold an army that was sit by the Messenger of Allah, peace be upon him and while the army was passing throw the Arab tribes they saw it and fear it and said: if those weren't very strong they won't go after the rum, we'll let them meet the rum. And then the army won the battle and returned safely and the arab bounced again to Islam.

This hadith narrated by Abu Hurayrah but after the end of the matter, after the death of Asiddiq, he swears three times that if it wasn't for Abu Bakr no one will worship Allah, so what are the qualities that characterized Asiddiq to do the right thing.

At the darkest positions and the most intriguing. It is clear here that the patient person his mind most likely weighs things and looks at the consequences and when this characteristic are available at nations they will not be affected by strife and will not be disturbed by calamities but they can cross to safety by mind and goodmeasure.

\footnotetext{
The third topic Immediately restore themselves to sanity after trouble: Calamities fall on the nations and peoples plus devastating crises and setbacks that blocks there march but living nations and peoples deal with all that out of a critical mindset. It put their failure is subject to criticism and review to find the causes and the factors, so, they get through the crises as the roman where described in the Hadith as they Immediately restore themselves to sanity after trouble.
}

Example for restoring sanity after a trouble from the prophet biography in what happened in Hamra al-Assad after the invasion of Badr, said Ibn Isaac (the day of Uhd was a day of calamity and scrutiny where Allah tested the believers and trial the Hypocrites) where Allah said in 3:172. Those [believers] who responded to Allah and the Messenger after injury had struck them. For those who did good among them and feared Allah is a great reward.

Altabari said that Allah In this verse pointed to Muslims who accompanied the Messenger to Hamra' al-Asad. The Messenger gathered the Muslims and urged them to pursue the unbelievers. Even though this was a highly critical moment, the true men of faith girded their loins and were prepared to lay down their lives at the behest of the Prophet. They accompanied him to Hamra' al-Asad, eight miles from Madina. The Prophet (peace and blessings of Allah be upon him) came out after the enemy with the calamities of killing and wounds among the Muslims. The death toll reached 70 as in al-Bukhari but this did not prevent them from proceeding with the greatest goal. We must quickly recover from the calamity, so, it won't leave a lasting impact, then the calamity turned into a grant and a reason to move forward. If we look at the history of Europe, we would see wonder in their ability to recover fast after calamities specially after world war two (Most of the German cities turned into wreckage and the smashed factories stopped as was the case in Western Europe, especially, Italy and the Netherlands. In France there were 55,000 destroyed factories, 135,000 buildings of agricultural facilities, 2 million dwellings, more than $7000 \mathrm{~km}$ of railways and 7500 bridges and roads. In England, industrial cities have become wrecked. The war left countless social problems: millions of people were homeless and millions of prisoners were suffering). Germany's loss of war was greater and involved all areas militarily, socially, politically and economically.

However, a short period of time only when these countries flourishes in the cultural production in various fields and recovered from the calamities in record time and for evidence the size of the economy of those countries. Table 1 shows the strongest eight countries in terms of purchasing power according to the International Monetary Fund for the year 2000 (in billion dollar), including five countries on rum behalf as in the Hadith.

If we look at some countries that possess huge natural resources, we find that they did not produce any civilized production but some exposed to natural disasters, famines and epidemic diseases due to poor management of crises and resources.

Immediately restore to sanity after trouble is a very important factor for permanence of civilization. Many civilizations were disappeared because they were not able to deal with crises. 
The Soc. Sci., 14 (12): 413-422, 2019

\section{The forth topic}

Attack again after fight: This part is a continues to the previous part but this one is related to military and self defense part and nations that surrender to its enemy accept to live in servile and submissive and won't be able to progress that why Allah initiated jihad, so, Islam nation spread justice and have the upper hand and Allah said in $61: 10+11$ (O you who have believed shall I guide you to a transaction that will save you from a painful punishment?10 [It is that] you believe in Allah and His Messenger and strive in the cause of Allah with your wealth and your lives. That is best for you, if you should know.11 and said in 9:111 Indeed, Allah has purchased from the believers their lives and their properties [in exchange] for that they will have Paradise. They fight in the cause of Allah, so, they kill and are killed. [It is] a true promise [binding] upon Him in the Torah and the Gospel and the Qur'an. And who is truer to his covenant than Allah? So, rejoice in your transaction which you have contracted. And it is that which is the great attainment.

Also, the Messenger of Allah peace be upon him cleared who important jihad is, Abu Hurairah said": A man came to the Messenger of Allah (SAW) and said: 'Tell me of an action that is equal to Jihad'. He said: 'I cannot. When the Mujahid goes out can you enter the Masjid and stand in prayer and never rest and fast and never break your fast?' He said: 'Who can do that?

We can see that leaving jihad will cause living in humble and submission and the nations who leave jihad won't be able to progress or make a civilization because their decision is in the enemy's hand whos taking all of their bounties, this nation would follow not lead and won't be allowed to progress, so, the Messenger of Allah peace be upon him talked about that in Ibn Omar may Allah bless them both Hadith: When you enter into the inah transaction, hold the tails of oxen are pleased with agriculture and give up conducting jihad (struggle in the way of Allah). Allah will make disgrace prevail over you and will not withdraw it until you return to your original religion. This is what the companions understood and translated in their actions, the Sedeeq said in his sermon (people do not let go of jihad for the sake of God, then Allah will beat them with humiliation) then after that all Islamic armies went out to protect the Islamic call and spread religion to the East and the West of Earth.

That's why fleeing from the battlefield is a major sin because it reflects a very bad results. Abu Hurairah (May Allah be pleased with him) said:

The Prophet (SAW) said, "Avoid the seven destructive things". It was asked: (by those present): "What are they, O Messenger of Allah?" he replied, "Associating anyone or anything with Allah in worship, practising sorcery, killing of someone without a just cause whom Allah has forbidden, devouring the property of an orphan, eating of usury, fleeing from the battlefield and slandering chaste women who never even think of anything touching chastity and are good believers.”

This part is talking about attacking again after fleeing but in Islam fleeing is a major sin unless in two cases in $8: 15,16$. O you who have believed when you meet those who disbelieve advancing [for battle] do not turn to them your backs [in flight]. And whoever turns his back to them on such a day, unless swerving [as a strategy] for war or joining [another] company has certainly returned with anger [upon him] from Allah and his refuge is Hell and wretched is the destination.

Here, we can relate to the Hadith when said attack again after fight. Alqurtobi said about this verses (the Muslim who swerve in the battlefield is non defeated also the one whos joining another company is also non defeated) and in the roman history, we see this quality clearly and the Quran talked about that is Surratt Al-Rum 2-4 (The Byzantines have been defeated2 In the nearest land. But they, after their defeat will overcome.3 within three to nine years. To Allah belongs the command before and after. And that day the believers will rejoice 4) even if it took some time but eventually they returned to the battlefield. Ibn Hesham talked about that when the Islamic army returned from the Battle of Mutah, the people thought that they flee but the messenger said they didn't flee they will attack again later

In modern European history, we find Germany, after losing World War I is back with great armies in a short period of time.

\section{The fifth topic}

Being good to the destitute the orphans and to the weak: In this section, an important characteristic is the saving the rights of the vulnerable and there are three varieties combined with the ease of being oppressed by the community around them.

The first one is the destitute and he is who was humiliated by poverty or other conditions, (Ibn Arafa said if he was humiliated by poverty he has the right of charity but if other condition he loses the right of charity because sometime, we use the word destitute for the people who got humiliated by some circumstances though they live in blessing, so, this type is not allowed to take charity). So, the destitute if poor or not is someone can be easily oppressed by the society around them.

The second one is the orphan: (The one who loses parent, if male he need care till Maturity, if female she need care till marriage), so from the definition we find the orphan is someone young lost his upholding and his right keeper in the society and can get easily coned since he don't know how to manage his money. In a solid society the orphan rights are safe from the people who try to con and deceit them. 
The third one is the weak: Weakness reverses strength in health, vision, opinion and welling and the weak is someone lost the ability of being active. Mental impairment is weakness in mental condition yet not crazy. The weaknesses are inability.

So, the three types the destitute the orphan and the weak exists in all societies and the society is combined to save their rights and help them not to get oppressed since they can easily oppressed and Islam teachings reached a huge level in keeping their rights and save them from being oppressed and also gave great rewards for those who help them.

Allah almighty distinguished the destitute in the Quran and made their right priority after kin( relatives) and said in 17:26 And give the relative his right, and [also] the poor and the traveler and do not spend wastefully. And in 30:38 so, give the relative his right, as well as the needy and the traveler. That is best for those who desire the countenance of Allah and it is they who will be the successful. And in 24:22 And let not those of virtue among you and wealth swear not to give [aid] to their relatives and the needy and the emigrants for the cause of Allah and let them pardon and overlook. Would you not like that Allah should forgive you? And Allah is forgiving and merciful.

God has made ransom and expiation related to the poor such as: *Expiation for Iftar for those who cannot fast like the sick who cannot be curedand the elders in verse 2:184 [Fasting for] a limited number of days. So, whoever among you is ill or on a journey [during them]- then an equal number of days [are to be made up]. And upon those who are able [to fast but with hardship] a ransom [as substitute] of feeding a poor person [each day]. And whoever volunteers excess it is better for him. But to fast is best for you, if you only knew.

*The expiation of swearing modifies the feeding of ten poor people, Allah said in 5:89 Allah will not impose blame upon you for what is meaningless in your oaths but he will impose blame upon you for [breaking] what you intended of oaths. So, its expiation is the feeding of ten needy people from the average of that which you feed your [own] families or clothing them or the freeing of a slave. But whoever cannot find [or afford it] then a fast of three days [is required]. That is the expiation for oaths when you have sworn. But guard your oaths. Thus, does Allah make clear to you his verses that you may be grateful.

*The expiation of hunting in Alharam is adjusted like the value of what was killed of the cattle or feed the poor as much as the value of those killed from those cattle and the Almighty said in 5:950 you who have believed, do not kill game while you are in the state of ihram. And whoever of you kills it intentionally the penalty is an equivalent from sacrificial animals to what he killed as judged by two just men among you as an offering [to
Allah] delivered to the Ka'bah or an expiation: the feeding of needy people or the equivalent of that in fasting, that he may taste the consequence of his deed. Allah has pardoned what is past but whoever returns [to violation], then Allah will take retribution from him. And Allah is exalted in might and owner of retribution.

*The expiation of those who pronounce Thihar from their wives and then [wish to] go back on what they said is adjusted in feeding 60 poor and Allah said in 58:3,4 And those who pronounce thihar from their wives and then [wish to] go back on what they said then [there must be] the freeing of a slave before they touch one another. That is what you are admonished thereby and Allah is Acquainted with what you do. And he who does not find [a slave] then a fast for two months consecutively before they touch one another and he who is unable then the feeding of sixty poor persons. That is for you to believe [completely] in Allah and his Messenger and those are the limits [set by] Allah. And for the disbelievers is a painful punishment.

And in another verses Allah criticizes the corrupted societies for not urging people to feed the poor in verse $89: 17,18$ No! But you do not honor the orphan and you do not encourage one another to feed the poor.

In verse 107:1,2,3 have you seen the one who denies the recompense? For that is the one who drives away the orphan and does not encourage the feeding of the poor.

And in verse 69:33,34 indeed, he did not used to believe in Allah, the most great, nor did he encourage the feeding of the poor.

Islam has preserved the right of the poor and Allah showed us that in many verses in Quran and saving the rights for the weakest in a basic part of the Islamic society. Also the messenger pointed to that clearly in the Hadith narrated by Abu Hurairah (May Allah be pleased with him) The Prophet peace be upon him said, "One who strives to help the widows and the poor is like the one who fights in the way of Allah". The narrator said: I think that he peace be upon him added also: "I shall regard him as the one who stands up (for prayer) without rest and as the one who observes fasts continuously".

Making helping the widows and the poor equal to jihad and stands up (for prayer) without rest and as the one who observes fasts continuously has a deep and holy value to Muslims and it has a very big reward as it also benefits the society and shows social solidarity.

On the other hand, Allah almighty mentioned the orphans in many verses and asked his worshipper to take care of them and gave big rewards for that and he also gave the orphans right in the Zakah money and in charity. For the great affair of the orphan in Islam teachings and the intensity of caring of them Allah said two verses in two suras of Quran including a great prohibition and severe warning about taking his money, so, he aske us to stay away of the orphan money unless it will do good for 
him. He almighty said in 6:152 and do not approach the orphan's property except in a way that is best until he reaches maturity. And give full measure and weight in justice. We do not charge any soul except [with that within] its capacity. And when you testify, be just, even if [it concerns] a near relative. And the covenant of Allah fulfill. This has he instructed you that you may remember. and in 17:34 And do not approach the property of an orphan, except in the way that is best, until he reaches maturity. And fulfill [every] commitment. Indeed, the commitment is ever [that about which one will be] questioned and said in another verse in 4:10. Indeed, those who devour the property of orphans unjustly are only consuming into their bellies fire. And they will be burned in a Blaze.

There are many verses in Quran that assure to take care of the orphan and made it a principle in Muslims hearts, so no one would harm the orphan or con them, since, they are weak and vulnerable. And there are many examples in the messenger biography were he encourages Muslims to take care of the vulnerable such Sahl bin Sa'd (May Allah be pleased with him) reported: Messenger of Allah (peace be upon him) said, "I will be like this in Jannah with the person who takes care of an orphan". Messenger of Allah (peace be upon him) raised his forefinger and middle finger by way of illustration. To be in Jannah next to the messenger is a very big dream for all Muslims and the prophet of Allah told this reward, so, the solidarity Islamic community won't take his site off the orphans. And in another Hadith It was narrated from Abu Hurairah that the Messenger of Allah(peace be upon him) said: "The best house among the Muslims is a house in which there is an orphan who is treated well. And the worst house among the Muslims is a house in which there is an orphan who is treated badly".

The last category is the weak who can't get their rights and in a sold society the rights of the weak are safe in justice. Islam teachings reached high levels in guiding people to take care of the weak and we see this obvious in Hadith were the prophet peace be upon him said: May that nation not be cleansed (of sin) among whom the weak cannot get their rights without trouble.' ”

This approach was understood by companions and followed as when Abu Baker said in his speech: The weak in you is strong with me until I remove his weakness in Gods willing and the strong of you is weak with me until I take the rights from him, in Gods willing.

Justice is a divine approach were God has established the heavens and the earth biased on it and ordered the creation to follow and judge with it. Allah said in 57:25. We have already sent Our messengers with clear evidences and sent down with them the scripture and the balance that the people may maintain [their affairs] in justice. And in 5:8 O you who have believed, be persistently standing firm for Allah, witnesses in justice and do not let the hatred of a people prevent you from being just. Be just, that is nearer to righteousness. And fear Allah, indeed, Allah is Acquainted with what you do. Also in 16:90 indeed, Allah orders justice and good conduct and giving to relatives and forbids immorality and bad conduct and oppression. He admonishes you that perhaps you will be reminded.

There are many verses that talking about justice as the basic of Islam and it is what assure to the weak their rights and how important that is for the permanence of the civilization, Ibn Taymiya said that God establishes a just state, even if it is infidel and does not establish oppression state, even if it is Muslim, also said life can be established with justice and infidel but won't with oppression and Islam.

\section{The sixth topic}

They put resistance against the oppression of kings: This quality is the most important in permanence of civilization which is putting resistance against oppression on people by people capable to oppression as kings. This quality if found would be the reason for nations to live in prosperity and keep developing civilization. Ruling people is the greatest duty in religion and it won't rise without it even life won't for that Omar Bin Abdulaziz wrote to his worker in Homs city (The city of Homs was destroyed and needed to be repaired and Omar wrote to him: fort it with justice and clear its roads from oppression, peace. Wisdom people said: there is no good in the ruler nor his ruling if he forbid justice).

When the ruler and his guards have absolute power the rule is dictatorial. Dictatorial is a Latin word that means giving total power to one person or one group and force laws on people and if look into the history, we will find that all dictatorial rulers demolished their people and their selves for example Pharaoh when Allah told us about him in 7:137. And we caused the people who had been oppressed to inherit the eastern regions of the land and the western ones which we had blessed. And the good word of your lord was fulfilled for the children of Israel because of what they had patiently endured. And we destroyed [all] that Pharaoh and his people were producing and what they had been building.

In this verse, we find what Pharaoh made and his people and the degree of tyranny of Pharaoh and oppression of judgment. In the verse 40:29 Pharaoh said, "I do not show you except what I see, and I do not guide you except to the way of right conduct”.

Nowadays, we find many examples like Moselini, Hitler, Stalin and many others who perished the plowing and offspring and the most misfortunes of peoples in mankind is the rule of the rulers. When viewing Islam teaching regarding State characteristics, we find it seeking a liberal state based on justice by unifying loyalty to Allah so, people get rid of slavery and being controlled. 
Mawardi defined ruling as the succession of prophecy, guarding religion and politics. Then ruling shouldn't make the one person controls all but it is succession of prophecy in Platform and law set by Allah that ensure all right for all people, Allah said in hen we put you, [O Muhammad], on an ordained way concerning the matter [of religion]; so, follow it and do not follow the inclinations of those who do not know. And in 5:48 and we have revealed to you, [O Muhammad], the book in truth, confirming that which preceded it of the scripture and as a criterion over it. So, judge between them by what Allah has revealed and do not follow their inclinations away from what has come to you of the truth. To each of you, we prescribed a law and a method. Had Allah willed, He would have made you one nation [united in religion], but [he intended] to test you in what he has given you; so, race to [all that is] good. To Allah is your return all together and he will [then] inform you concerning that over which you used to differ.

Allah prepared for the rulers of people a great reward in Hadith Abu Hurairah (May Allah be pleased with him) reported:

The Prophet (SAW) said, "Seven are (the persons) whom Allah will give protection with his shade* on the day when there will be no shade except his shade (i.e., on the day of resurrection) and they are: A just ruler, a youth who grew up with the worship of Allah, a person whose heart is attached to the mosque, two persons who love and meet each other and depart from each other for the sake of Allah, a man whom a beautiful and high ranking woman seduces (for illicit relation) but he (rejects this offer by saying): 'I fear Allah', a person who gives a charity and conceals it (to such an extent) that the left hand might not know what the right has given, and a person who remembers Allah in solitude and his eyes well up."

Abdullah bin 'Amr bin Al-' as (May Allah be pleased with them) reported: the Messenger of Allah (SAW) said, "The just will be seated upon pulpits of light”. Those who are fair with regards to their judgement and their family and those who are under them".

Though Allah warned and vowed of injustice and treachery of rulers and in Hadith Abu Sa'id Al-Khudri (May Allah be pleased with him) said:

The Prophet (SAW) said, "Everyone who breaks a covenant will have a flag by his buttocks on the day of resurrection. It will be raised higher according to the nature of his breach. Behold, there will be no greater a sin with respect to breaking the covenant than that of a ruler who breaks his covenant with the Muslim masses".

And in Islam there is a great reward for people fighting injustice and tyranny because it's corrupting and in HadithAbu Sa'id Al-Khudri (May Allah bepleased with him) reported:

The Prophet (SAW) said, "The best type of Jihad (striving in the way of Allah) is speaking a true word in the presence of a tyrant ruler" and in another Hadith. From Jabir, may Allah be pleased with him the prophet (peace and blessings of Allah be upon him). Said: (The master of martyrs Hamza bin Abdul Muttalib and a man is speaking a true word in the presence of a tyrant then was killed).

Also in Quran 3:187 And [mention, O Muhammad], when Allah took a covenant from those who were given the Scripture, [saying], "You must make it clear to the people and not conceal it". But they threw it away behind their backs and exchanged it for a small price. And wretched is that which they purchased.

All this because the general mandate has a fundamental and dangerous role in the continuity of civilization and the prosperity of the peoples. If this condition is met in a nation of nations (preventing the oppression of rulers), it has a great share in living in prosperity and outperforming others in all areas of life.

That is why Muslim scholars have set conditions that must be met in the Imam taken from the religious evidence as follows ${ }^{(63)}$ :

Justice on all of its terms is intended to be the ruler should have integrity in the biography and avoid the acts of debauchery and immorality and not be unjust and treachery.

Should hold science leading to diligence in the downturns and rulings to have a high degree of knowledge to reach the degree of diligence in the assets and branches in order to be able to implement Islamic law and prevent suspicions about the faith and give fatwas in matters because the main purpose in the ruling is to maintain the faith and solve problems and conflicts.

The integrity of the senses of hearing and sight and speaking to be knowingof what is aware of. The safety of organs from deficiency prevents movement and rapid rise. To be the owner of an opinion and policy resulting from sophistication and experience and understanding of reality.

To have courage and jihad of the enemy and protecting the Earth because the leader is the commander of the Islamic armies, it is not right to be a coward and fail to defend Islamic issues.

The descent is to be from the Quraysh to the text in it and according to the people of the sunnah, a requirement unanimously but some of the jurists tend to cancel this condition, such as Ibn Khaldun.

These deduced conditions are evidence of Islam's interest in the position of ruler because of its importance in building the civilization of Islam that promotes justice, prosperity and equality among all human beings and abandon them leads to spread injustice and corruption, according to the Hadith Allah's Messenger (SAW) said, "When honesty is lost, then wait for the hour". It was asked, "How will honesty be lost, O Allah's Messenger (SAW)?” He said, "When authority is given to those who 
do not deserve it, then wait for the hour.". This Hadith means that if the authority is in the wrong hand it will cause danger to nations.

The results of the search are: the Hadith explain the most important reasons for the of permanence civilization and prosperity.

Patient is a great Islamic moral urged by the Quran and the Prophet and one of the reasons for the permanence of civilization immediately restore selves to sanity after trouble and attack again after fight these qualities are the characters of living nations. Being good to the destitute the orphans and to the weak is an evidence of Humanitarian community that deserves to live in prosperity because they don’t oppress the weak layer.

\section{CONCLUSION}

For a thriving civilization must be justly judged, the fate of every dictator is to perished and he shall destroy the peoples that have undergone him and destroy their civilization.

The advanced civilizations of our time need a lot of studies and link them to the reasons that enabled them and explore the reasons for their progress.

\section{REFERENCES}

Abdulaziz, O. and M.A. Al-Qawzi, 1999. Studies in Modern and Contemporary European History, 1815-1950. Dar Al Nahda Al Arabiya, Beirut, Lebanon,.

Abu Abdullah, 2000. Interpretation of the Names of Allah Realization: Obaid bin Ali Al-Obaid. Islamic University of Madinah, Medina, Saudi Arabia,.

Abu Al-Fida, 1998. Tafseer of the Great Quran Detective: Mohammad Hussein Shams Al-Din. 1st Edn., Publications of Mohamed Ali Beydoun, Arab Book House, Beirut, Lebanon,.
Abu Al-Fidaa, 1982. Chapters in Biography, Investigation and Commentary: Muhammad al-Eid al-Kutt al-Ruwi, Mohiuddin Mesto. 3rd Edn., Quran \& Science Research Foundation, Lebanon,.

Abu Al-Hasan, 2006. Royal Verification. Dar al-Hadith al-Nuriyya, Cairo,.

Abu Al-Qasim, 1986. Scouting for the Facts of the Mysterious Download. 3rd Edn., Dar al-Kitab al-Arabi, Beirut, Lebanon,.

Abu Al-Qasim, 1991. Vocabulary in Gharib Al-Quran Inquiry: Safwan Adnan Al-Daoudi. Dar Al-Qalam, Beirut, Lebanon,.

Abu Bakr, M.M.W.M., 1872. Fihri Tartooshi Siraj Kings. Arab Publishers, Cairo, Egypt,.

Abu Khalil, S., 1996. Arab-Islamic Civilization and a Summary of Previous Civilizations T 2 Beirut Damascus. House of Contemporary Thought, Beirut, Lebanon,.

Abu Zakaria, 1972. Alminhaj Sharh Sahih Muslim Bin Alhjaj. 2nd Edn., Dar Ihya al-Turath al-Arabi Publisher, Beirut, Lebanon,.

Ahmad, F.Z.Q.R.A.H., 1978. A Dictionary of Language Standards Achievement: Abdulsalam Mohammad Haroon. Thinkers Publishing, Lebanon,.

Ahmed, M. and O. Abdul-Hamid, 2008. With the Help of a Team, Dictionary of Contemporary Arabic. 1st Edn., Alam Al Kotob, Cairo, Egypt,.

Mohammed Bin Isa, 1998. Sunan Tirmidhi, Investigation. Dar al-Gharb al-Islami, Beirut, Lebanon,.

Mohammed, J.Y.K.G.A.J.T., 1999. Al-Bayan Collection in the Interpretation of the Koran Inquiry. 1st Edn., Shaker Foundation, Cairo Egypt,.

Taqi Al-Din Abu Al-Abbas, 1995.. Total Fatwas Achieved by: Abdulrahman bin Mohammed bin Qasim Print King Fahd Complex. Holy Quran Madinah Al-Nabawiya, Saudi Arabia,. 